\title{
Mengatasi Kabut Asap Melalui Mekanisme \\ Citizen Lawsuit
}

Oleh: Mulyani Zulaeha ${ }^{1}$

\begin{abstract}
Abstrak
Permasalahan kabut asap akibat terbakarnya hutan dan lahan di Indonesia merupakan kejadian berulang setiap tahun. Dampak kabut asap tidak saja dialami oleh masyarakat sekitar, namun juga berdampak ke wilayah lain di Indonesia bahkan menjadi kado tahunan bagi beberapa negara tetangga Indonesia. Kerugian yang diderita tidak saja bersifat materiil bahkan sampai merenggut nyawa. Dengan metode yuridis normatif, dapat dijelaskan persoalan kabut asap yang mengakibatkan warga negara tidak mendapatkan haknya atas lingkungan udara yang baik dan sehat dapat di jadikan sebagai dasar mengajukan gugatan citizen lawsuit. Gugatan dilakukan agar penyelenggara negara mengeluarkan suatu kebijakan yang bersifat umum agar kelalaian atau kegagalan dalam pemenuhan hak warga negara tersebut di masa mendatang tidak terjadi lagi. Potensi mengatasi kabut asap melalui mekanisme citizen lawsuit yaitu pemerintah akan mengeluarkan suatu aturan yang lebih tegas agar kejadian kabut asap tidak lagi terulang.
\end{abstract}

Kata Kunci : Kabut asap, Citizen Lawsuit, kebakaran hutan dan lahan

\section{Abstract}

Problem of smoke fog effect of burnt of farm in Indonesia represent recurring occurance every year. Fog smoke impact is not even experienced of by society about, but also effect to

1 Penulis adalah Dosen pada Fakultas Hukum Universitas Lambung Mangkurat Banjarmasin, Bidang Kekhususan Hukum Acara. 
other region in Indonesia even become annual souvenir to some Indonesia neighbouring state. Suffered loss not even the character of material even snatch soul. With method can be explained by problem of smoke fog resulting citizen do not get its rightsof healthy and good air environment earm in making as suing base of citizen lawsuit. Suing conducted government body to release an policy arranging failure to or negligence in accomplishment of the citizen rights in period to come do not happened again. Potency overcome smoke fog through mechanism of citizen law suit that is government will release an more coherent order so that occurance of smoke fog shall no logger recurred.

Keywords : forest haze, Citizen Lawsuit, forest and land fires

\section{Pendahuluan}

Udara sebagai media lingkungan merupakan kebutuhan dasar manusia, tanpa udara tidak akan dapat hidup. Lingkungan udara memiliki fungsi yang sangat vital bagi kehidupan manusia, menjaga keberlangsungan fungsinya adalah mutlak menjadi tanggung jawab bersama. Udara yang bersih akan menciptakan kondisi lingkungan yang sehat dan bersih, ditandai dengan kualitas udara yang bebas dari pencemaran udara. ${ }^{2}$ Pencemaran udara menurut Pasal 1 angka 1 Peraturan Pemerintah Nomor 41 Tahun 1999 tentang Pengendalian Pencemaran Udara adalah masuknya atau dimasukkannya zat, energi, dari komponen lain ke dalam udara ambient oleh kegiatan manusia, sehingga mutu udara turun sampai ketingkat tertentu yang menyebabkan udara ambient tidak dapat memenuhi fungsinya. Menurut Pasal 1 angka 14, pencemaran lingkungan hidup adalah masuk atau dimasukannya makhluk hidup, zat, energi, dan/ atau komponen lain ke dalam lingkungan hidup oleh kegiatan manusia sehingga melampaui baku mutu lingkungan hidup yang telah ditetapkan.

Kabut asap merupakan salah satu bentuk pencemaran udara yang terjadi sebagai imbas dari adanya kebakaran hutan atau lahan, baik yang dilakukan atas dasar kesengajaan atau terjadi karena faktor alam. Faktor kesengajaan melakukan

2 Pencemaran udara diartikan sebagai keadaan atmosfir, dimana satu atau lebih bahan-bahan polusi yang jumlah dan konsentrasinya dapat membahayakan kesehatan makhluk hidup, merusak properti, mengurangi kenyamanan di udara. Lihat Hadin Muhjad. 2015. Hukum Lingkungan: Sebuah Pengantar Untuk Konteks Indonesia. Yogyakarta : Genta Publishing. hlm 127. 
pembakaran hutan /lahan lebih dominan menjadi pemicu terjadinya kabut asap. Udara yang kita hirup tidak dapat disekat-sekat. Terjadinya pencemaran udara di suatu wilayah akan dirasakan pula dampaknya di wilayah lain, bahkan dalam radius puluhan dan ratusan kilometer. Hal ini terjadi karena persoalan lingkungan merupakan satu kesatuan ekosistem yang memiliki keterkaitan satu sama lain tanpa mengenal batas wilayah. Kebakaran hutan dan lahan tahun 2015 di Sumatera dan Kalimantan, dampak kabut asapnya dihirup oleh masyarakat di beberapa provinsi lain bahkan sampai ke luar Indonesia.Menurut Badan Nasional Penanggulangan Bencana (BNPB) tahun 2015 sebaran kabut asap yang berasal dari Sumatera dan Kalimantan menyebabkan puluhan ribu jiwa terpapar asap mengakibatkan meningkatnya jumlah penderita Inveksi Saluran Pernapasan Akut (ISPA), ${ }^{3}$ serta berdampak pula pada kualitas udara di beberapa negara tetangga seperti Malaysia, Singapura, dan yang terburuk terjadi di Thailand. ${ }^{4}$

Luas area kebakaran hutandan lahan tahun 2015 setara dengan 32 kali wilayah provinsi DKI Jakarta atau empat kali Pulau Bali atau seluas 2.089.911 hektare ${ }^{5}$, Total kerugian negara akibat kebakaran hutan dan lahan tahun 2015 diperkirakan lebih dari Rp. 20 triliun, ${ }^{6}$ angka ini jauh melebihi kerugian negara dalam kasus korupsi

3 Jumlah korban ISPA akibat asap yang terdata di Rumah Sakit dan Puskesmas adalah 503.874 jiwa di 6 provinsi sejak 1 juli-23 oktober 2015, dengan perincian 80.263 di Riau, 129.229 di Jambi, 101.333 di Sumatera Selatan, 43.477 di Kalimantan Barat, 52142 di Kalimantan Tengah dan 97.430 di Kalimantan Selatan. Lihat 10 Tewas, 503 Ribu Jiwa ISPA, dan 43 Juta Jiwa Terpapar Asap, BNPB.go.id, tanggal 24 Oktober 2015, diakses tanggal 24 Maret 2016.

4 Asap Kebakaran Hutan Sampai Jakarta, www.bbc.com>Indonesia>2015. tanggal 24 Oktober 2015. Diakses tanggal 10 Pebruari 2016.

5 Sutopo Purwo Nugroho, Kepala Pusat Data dan Informasi Badan Nasional Penanggulangan Bencana (BNPB), Lihat BNPB : Kebakaran Hutan 2015 Seluas 32 Wilayah DKI, CNN Indonesia. com, tanggal 31 Oktober 2015, diakses tanggal 24 Maret 2016. Menurut Lembaga Penerbangan dan Antariksa Nasional (Lapan) dengan menggunakan data terra modis didukung densitas hotspot satelit Terra\&Aqua dan Satelit SNPP dengan sensor modis, merilis luas lahan terbakar 1 Juli-20 Oktober 2015,luas area terbakar terdiri dari Sumatera 832.99 hektare (267.974 hektar gambut, 565.025 non gambut), Kalimantan 806.817 hektare (319.386 hektare gambut, 478.431 non gambut), Papua 353.191 hektare (31.214 hektare gambut, 321.977 hektare non gambut), lahan terbakar non gambut di Sulawesi 30.162 hektare, Jawa 18.768 hektare dan Maluku 17.063 hektare. Lihat Tiga Bulan, Hutan dan Lahan Terbakar Setara 4 kali Luas Bali.Mongabay.com Situs Berita Informasi Lingkungan, tanggal 31 Oktober 2015, di akses tanggal 24 Maret 2016.

6 BNPB :Kebakaran Hutan......Ibid. 
dan suap. ${ }^{7}$ Besarnya total kerugian negara akibat kebakaran hutan dan lahan perlu mendapatkan perhatian serius.

Lingkungan (udara) yang baik dan sehat adalah hak asasi warga negara, negara bertanggung jawab atas pemenuhan hak asasi warga negara ini. Negara harus dapat memberikan perlindungan hak asasi manusia, terutama hak untuk mendapatkan udara yang baik dan sehat. Bentuk pemenuhan atas perlindungan hak warga negara untuk mendapatkan lingkungan udara yang baik dan sehat dapat berupa perlindungan yang bersifat preventif yaitu pencegahan agar tidak terjadi, maupun berupa perlindungan yang bersifat refresif. Meskipun berbagai peraturan dan upaya telah dilakukan oleh pemerintah terkait kebakaran hutan dan lahan sebagaimana tertuang dalam Undang-Undang Republik Indonesia Nomor 32 Tahun 2009 tentang Perlindungan dan Pengelolaan Lingkungan Hidup, UndangUndang Republik Indonesia Nomor 41 Tahun 1999 tentang Kehutananyang telah diubah dengan UU Nomor 19 Tahun 2004, Undang-Undang Nomor 18 Tahun 2013 tentang Pencegahan dan Pemberantasan Perusakan Hutan, Undang-Undang Republik Indonesia Nomor 39 Tahun 2014 tentang Perkebunan, namun belum cukup efektif mengatasi tidak terulangnya kejadian kabut asap akibat kebakaran hutandanlahan. Sehingga setiap tahun masyarakat Indonesia selalu menerima menu tahunan berupa kabut asap.

Penyelesaian sengketa atas lingkungan hidup yang buruk sebagai akibat pencemaran atau kerusakan lingkungan telah diatur dalam undang-undang yang dapat dilakukan dengan jalur pengadilan maupun di luar pengadilan. Jalur pengadilan yang dapat ditempuh baik oleh Pemerintah maupun oleh masyarakat. Upaya yang dapat dilakukan oleh masyarakat untuk mendapatkan pemenuhan hak atas udara yang baik dan sehat secara perdata adalah dengan mengajukan gugatan. Gugatan dapat diajukan dalam bentuk gugatan perwakilan kelompok (class action), hak gugat organisasi (legal standing), dan gugatan warga negara (citizen lawsuit/action popularis).

7 Data Indonesia Corruption Watch (ICW) Komisi Pemberantasan Korupsi rata-rata menyidik 15 kasus korupsi selama periode 2010-2014, kerugian Negara kurun waktu itu Rp 1,1 triliun, dan selama semester 1 tahun 2015 KPK menyidik kasus korupsi dengan kerugian Negara Rp. 106,4 miliar. Ibid. 
Diantara ketiga gugatan yang dapat dilakukan oleh masyarakat maka gugatan warga negara (citizen lawsuit/action popularis) merupakan mekanisme yang relatif baru dikenal di Indonesia. Gugatan citizen lawsuit bukan gugatan yang berujung pada tuntutan gantikerugian, melainkan tuntutan berupa dikeluarkannya kebijakan bersifat umum oleh pemerintah. Berdasarkan uraian di atas, maka menarik untuk dilakukan suatu pembahasan tentang upaya warga negara untuk mendapatkan hak atas lingkungan udara yang baik dan sehat melalui mekanisme citizen lawsuit dan bagaimana potensi mekanisme citizen lawsuit dalam menyelesaikan kabut asap agar tidak terulang. Analisis untuk membahas persoalan ini dilakukan dengan metode yuridis normatif melalui pendekatan undang-undang ${ }^{8}$ dan pendekatan konsep. ${ }^{9}$

\section{Perlindungan Hak Asasi Manusia Terhadap Lingkungan (Udara) yang Baik dan Sehat}

Keberadaan hak asasi manusia membawa pengaruh positif dalam berbagai bidang kehidupan, Pemerintah berupaya melaksanakan pembangunan dengan berorientasi pada pendekatan hak asasi manusia, agar segala perubahan yang ada tidak merugikan hak-hak yang dimiliki oleh warga negaranya. Dengan kata lain, pendekatan berbasis hak asasi diyakini akan membawa proses pembangunan kearah perubahan yang lebih efektif, lebih berkelanjutan, lebih rasional dan lebih sungguh-sungguh karena akan meningkatkan partisipasi, kontribusi dan akuntabilitas, dengan mengidentifikasi secara spesifik tugas dan tanggung jawab negara sebagai pemangku kewajiban hak asasi atas pembangunan. ${ }^{10}$

Penyelenggara Negara Republik Indonesia adalah pengemban amanat Pembukaan UUD 1945, yakni untuk melindungi, memajukan, menegakkan dan menjamin pemenuhan hak asasi setiap warga Negara Republik Indonesia.

8 Pendekatan undang-undang yaitu dilakukan dengan menelah semua undang-undang dan regulasi yang bersangkut paut dengan isu hukum yang sedang ditangani

9 Pendekatan yang dilakukan dengan cara melakukan penelusuran terhadap pandanganpandangan dan doktrin-doktrin yang berkembang dalam ilmu hukum yang bersumber dari pendapat para ahli maupun teori.

10 Muhammad Syafari Firdaus (et.all).2007. Pembangunan Berbasis Hak Asasi Manusia: Sebuah Panduan. Jakarta : Komisi Nasional HAM Bekerjasama dengan Australian Government (AusAID). hlm. 3. 
Sebagaimana dipertegas dalam batang tubuh UUD 1945 yaitu Pasal 28 I ayat (4) UUD 1945, "Perlindungan, pemajuan, penegakan dan pemenuhan hak asasi manusia adalah tanggung jawab negara, terutama Pemerintah". Undang-Undang Nomor 39 Tahun 1999 tentang Hak Asasi Manusia (HAM), Pasal 8, "Perlindungan, pemajuan, penegakan, dan pemenuhan hak asasi manusia terutama menjadi tanggung jawab Pemerintah".

Lingkungan terdapat dua komponen penting yaitu komponen biotik dan abiotik. Udara merupakan salah satu komponen abiotik yang bermanfaat bagi kelangsungan hidup makhluk hidup.Manusia dan lingkungan hidup memang tidak dapat dipisahkan, diperlukan keselarasan hubungan antara manusia dan lingkungan hidup, baik lingkungan hidup fisik maupun lingkungan sosial budaya. ${ }^{11}$ Keselarasan antara pemanfaatan lingkungan hidup oleh manusia dengan pengelolaan lingkungan hidup merupakan keniscayaan karena lingkungan hidup yang baik dan sehat merupakan hak asasi dan hak konstitusional bagi setiap warga negara Indonesia, sebagaimana dinyatakan dalam Undang-Undang Dasar Negara Republik Indonesia Tahun 1945 Pasal 28H ayat (1), menyebutkan "setiap orang orang berhak hidup sejahtera lahir dan bathin, bertempat tinggal dan mendapatkan lingkungan hidup yang baik dan sehat serta berhak mendapatkan pelayanan kesehatan". Selanjutnya ketentuan tersebut diimplementasikan dalam Pasal 65 ayat (1) Undang-Undang Nomor 32 tahun 2009 tentang Perlindungan dan Pengelolaan Lingkungan Hidup, menyebutkan "setiap orang berhak atas lingkungan hidup yang baik dan sehat sebagai bagian dari hak asasi manusia", demikian juga dalam Undang-Undang Nomor 39 Tahun 1999 tentang HAM, Pasal 3 menyebutkan " masyarakat berhak atas lingkungan hidup yang lebih baik dan sehat". Makna dari ketentuan ini adalah negara memberikan jaminan terhadap hak atas lingkungan hidup yang baik sehat sebagai hak konstitusional bagi setiap warga negara Indonesia agar setiap orang terhindar dari pencemaran yang dapat membahayakan kesehatan masyarakat. Termasuk hak untuk mendapatkan udara yang baik dan sehat.

Hak atas lingkungan hidup yang baik dan sehat merupakan hak asasi juga dimuat dalam Penjelasan Umum Undang-Undang Nomor 32 tahun 2009 tentang

11 Koesnadi Hardjasoemantri. 1983. Hukum Tata Lingkungan. Cetakan ke-1, Yogyakarta : Gadjah Mada University Press. hlm 42. 
Perlindungan dan Pengelolaan Lingkungan Hidup, yaitu “Undang-Undang Dasar Negara Republik Indonesia Tahun 1945 menyatakan bahwa lingkungan hidup yang baik dan sehat merupakan hak asasi dan hak konstitusional bagi setiap warga Negara Indonesia. Oleh karena itu, Negara, pemerintah dan seluruh pemangku kepentingan berkewajiban untuk melakukan perlindungan dan pengelolaan lingkungan hidup dalam pelaksanaan pembangunan berkelanjutan agar lingkungan hidup Indonesia dapat tetap menjadi sumber dan penunjang hidup bagi rakyat Indonesia serta makhluk hidup lain".

Indonesia sebagai negara hukum modern yang demokratis, menjamin setiap warga negaranya memiliki hak yang sama di hadapan hukum, sebagaimana tertuang dalam Pasal 28D ayat (1) UUD 1945 yang menyatakan "Setiap orang berhak atas pengakuan, jaminan, perlindungan dan kepastian hukum yang adil serta perlakuan yang sama di hadapan hukum". Rasionalisasi dari jaminan ini menurut Jean Jacques Rousseau adalah bahwa warga negara merupakan pihak yang tidak terpisahkan dengan negara, karena negara disusun berdasarkan kontrak sosial antara warga negara/yang diperintah dengan penyelenggara negara/ yang memerintah. ${ }^{12}$ Sebagai aplikasinya rakyat berhak mengingatkan pemimpin negaranya apabila melakukan kesalahan yang mengakibatkan kerugian terhadap kepentingan umum.

\section{Landasan Yuridis Citizen Lawsuit di Indonesia}

Hak gugat warga negara atas kepentingan umum berangkat dari kesadaran untuk mengawal perlindungan hak asasi manusia. ${ }^{13}$ Citizen lawsuit adalah mekanisme gugatan sebagai perwujudan akses individual/orang perorangan warga negara untuk kepentingan keseluruhan warga negara atau kepentingan umum menggugat tanggung jawab penyelenggara negara atas kelalaian dalam memenuhi hak-hak warga negara. Kelalaian tersebut didalilkan sebagai perbuatan melawan hukum dalam memenuhi hak warga negara, sehingga citizen lawsuit diajukan dalam lingkup peradilan umum dalam hal ini perkara perdata.

12 Jean Jacques Rousseau dalam Isrok dan Rizki Emil Birham. 2010. Citizen Lawsuit: Penegakan Hukum Alternatif Bagi Warga Negara. Malang : UB Press. hlm 2.

13 Ibid, hlm 4. 
Secara umum citizen lawsuit adalah akses orang perorangan warga negara untuk kepentingan publik mengajukan gugatan di pengadilan yang dimaksudkan untuk melindungi warga negara sebagai akibat dari tindakan pembiaran (omisi) yang dilakukan negara terhadap hak-hak warga negara, ${ }^{14}$ agar pemerintah atau negara melakukan penegakan hukum yang diwajibkan kepadanya untuk memulihkan kerugian publik yang terjadi. ${ }^{15}$

Bentuk gugatan oleh warga negara yang mengatasnamakan kepentingan umum sampai saat ini belum diatur secara khusus dalam peraturan perundangundangan di Indonesia. Gugatan warga negara untuk menggugat penyelenggara negara merupakan mekanisme gugatan yang dikenal dalam sistem hukum common law. Citizen lawsuit di Amerika Serikat, Australia dan India lahir dan berkembang pesat khususnya dalam hukum lingkungan. ${ }^{16}$ Contoh kasus citizen lawsuit di Amerika Serikat adalah, Robert Cohen warga Negara Amerika Serikat menggugat FDA dan Department of Health and Human Services karena kedua lembaga tersebut telah melanggar Freedom of Act dengan tidak mempublikasikan pengetahuan kedua lembaga tersebut bahwa RBST (Recombinant Bovine Somatotropin) hormon yang disuntikkan pada sapi-sapi penghasil susu dapat memicu kanker pada manusia, padahal masyarakat Amerika Serikat banyak yang mengkonsumsi susu tersebut tanpa tahu bahayanya. Di India, seorang warga Negara India mengajukan citizen lawsuit mengatasnamakan kepentingan umum menggugat pemerintah India yang melalaikan pengelolaan sungai gangga sehingga tercemar, sedangkan sungai gangga bagi masyarakat Hindu di India merupakan tempat yang suci.

Pengakuan terhadap gugatan citizen lawsuit di Indonesia pertama kali dilakukan pada tahun 2003 berdasarkan pada ketentuan Pasal 16 ayat (1) UndangUndang Nomor 4 Tahun 2004 tentang Kekuasaan Kehakiman yaitu Hakim tidak boleh menolak perkara yang diajukan dengan alasan belum ada hukumnya. Pasal 27 Undang-Undang Nomor 35 Tahun 1999 tentang Perubahan Atas UndangUndang Nomor 14 Tahun 1970 tentang ketentuan Pokok Kekuasaan Kehakiman,

14 Susanti Adi Nugroho. 2010. Class Action dan Perbandingannya Dengan Negara Lain. Cetakan 1, Jakarta : Prenadia Media Group. hlm 385.

15 Dhabi K. Gumayra (Kontributor). 2006. Panduan Bantuan Hukum di Indonesia. Jakarta : Aussaid YLBHI, PSHK dan IALDF. hlm 382.

16 Indro Sugiantoro. 2004. Kasus Nunukan: Hak Gugat Warga Negara (Citizen Lawsuit) Terhadap Negara. Jurnal Kajian Putusan Pengadilan Dictum, Edisi 2. hlm 34. 
yaitu Hakim wajib menggali, mengikuti, memahami nilai-nilai yang hidup dalam masyarakat. Pasal 28 UUD 1945, Pasal 5 Undang-Undang Nomor 3 Tahun 2009 tentang Perubahan Kedua Atas Undang-Undang Republik Indonesia Nomor 14 Tahun 1985 tentang Mahkamah Agung bahwa Hakim menggali hukumnya dalam masyarakat.

Beberapa gugatan citizen lawsuit yang telah diterima di pengadilan adalah putusan Nomor 28/Pdt.G/2003/PN.Jkt.Pst mengenai penelantaran buruh migran di Nunukan, putusan Nomor 228/Pdt.G/2006/PN. Jkt.Pst mengenai gugatan korban penyelenggaraan ujian nasional, putusan Nomor 55/PDT.G/2013/ PN.SMDA mengenai penerbitan izin pertambangan batubara di Samarinda sebagai pemicu pemanasan global yang memperparah dampak terjadinya perubahan iklim di wilayah Kota Samarinda Kalimantan Timur.

Penerimaan model gugatan warga negara di Indonesia merupakan adaptasi guna menjawab berbagai peristiwa yang berkembang dalam masyarakat tidak hanya terbatas dalam konteks hukum materiil saja, namun hukum acara sebagai hukum formil yang berfungsi untuk menegakkan hukum materiil pun dilakukan. Penegakan hukum dalam perjalanannya harus dinamis mengikuti perkembangan lingkungannya. Hukum sebagai sarana pembaharuan masyarakat sebagaimana dikemukakan oleh Mochtar Kusumaatmadja mengisyaratkan bahwa pembangunan hukum tidak dapat dipisahkan dari perkembangan masyarakat dan diikuti pula dengan semakin berkembangnya kebutuhan hukum masyarakat. Untuk memenuhi kebutuhan hukum masyarakat yang berubah seiring dengan pesatnnya perkembangan teknologi informasi dan telekomunikasi, sistem hukum Indonesia yang menganut sistem civil law banyak mengadopsi mekanisme hukum yang berasal dari sistem hukum common law yang dianut oleh negara-negara anglo saxon. ${ }^{17}$

Beberapa mekanisme dalam upaya penegakan hukum di Indonesia yang mengadaptasi hukum asing yang bersumber pada sistem hukum common law, seperti legal standing, class action, decenting opinion, dan citizen lawsuit. Mekanisme class action secara formal telah diatur dalam Peraturan Mahkamah Agung No 1 Tahun 2002 tentang Acara Gugatan Class Action. Sedangkan untuk mekanisme citizen lawsuit belum diatur secara formal, namun Mahkamah Agung telah

17 Efa Laela Fakhriah. 2008. Actio Popularis (Citizen Lawsuit) Dalam Perspektif Hukum Acara Perdata. Makalah. hlm 1. 
menyatakan bahwa citizen lawsuit sebagai salah satu cara yang dapat digunakan untuk menyelesaikan perkara perdata lingkungan, yang tertuang dalam Keputusan Ketua Mahkamah Agung Republik Indonesia Nomor: 36/KMA/SK/II/2013 tentang Pemberlakuan Pedoman Penanganan Perkara Lingkungan Hidup, yang ditetapkan pada tanggal 22 Pebruari 2013.

\section{Mekanisme Gugatan Citizen LawsuitSebagai Upaya Untuk Mendapatkan Hak Dasar Berupa Lingkungan Udara yang Baik dan Sehat}

Gugatan warga negara adalah suatu gugatan yang dapat diajukan oleh setiap orang terhadap suatu perbuatan melawan hukum, dengan mengatasnamakan kepentingan umum. Kepentingan umum merupakan hakikat dari citizen lawsuit. Kepentingan umum yang dimaksud adalah kepentingan yang harus didahulukan dari kepentingan pribadi atau individu atau kepentingan lainnya, yang meliputi kepentingan bangsa dan negara, pelayanan umum dalam masyarakat luas, rakyat banyak dan atau pembangunan di berbagai bidang. Menurut Theo Huijber, kepentingan umum ialah kepentingan masyarakat sebagai keseluruhan yang memiliki ciri-ciri tertentu antara lain menyangkut perlindungan hak-hak individu sebagai warga negara dan menyangkut pengadaan serta pemeliharaan sarana publik dan pelayanan publik. ${ }^{18}$ Kepentingan umum dalam konteks penyelesaian lingkungan menurut Keputusan Ketua Mahkamah Agung Republik Indonesia Nomor: 36/KMA/SK/II/2013 tentang Pemberlakuan Pedoman Penanganan Perkara Lingkungan Hidup adalah kepentingan lingkungan dan kepentingan makhluk hidup yang potensial atau sudah terkena dampak pencemaran dan/atau perusakan lingkungan.

Syarat formil gugatan citizen lawsuit yang bersifat khusus adalah adanya pemberitahuan atau notifikasi yang dilakukan oleh penggugat kepada tergugat. Indonesia belum memiliki peraturan formal secara khusus berkaitan notifikasi dalam gugatan citizen lawsuit, sehingga beberapa hakim pengadilan memiliki pandangan dan penafsiran yang berbeda berkaitan dengan prosedur

18 Theo Huijber. 2000. Filsafat Hukum Dalam Lintasan Sejarah. Jakarta : UI Press. hlm 23. 
notifikasi. ${ }^{19} \mathrm{Hal}$ ini mengakibatkan beberapa gugatan citizen lawsuit dinyatakan tidak dapat diterima. ${ }^{20}$ Mekanisme notifikasi yang berlaku di Amerika Serikat, yaitu pemberitahuan harus dikirimkan kepada tergugat paling lambat 60 hari sebelum gugatan diajukan.Maksud pemberitahuan ini adalah proses khusus semacam somasi, dalam bentuk statement dari penggugat kepada tergugat yang berisi dasar pelanggaran dan tuntutan spesifik yang dimintakan. Notifikasi merupakan tahap pendahuluan dari gugatan citizen lawsuit yang sekurang-kurangnya memuat informasi tentang informasi pelaku pelanggaran dan lembaga yang relevan dengan pelanggaran, jenis pelanggaran, peraturan perundang-undangan yang telah dilanggar, dan kepentingan umum yang dimaksud.

Notifikasi untuk perkara perdata lingkungan secara khusus terdapat dalam Keputusan Ketua Mahkamah Agung Republik Indonesia Nomor: 36/KMA/ SK/II/2013 tentang Pemberlakuan Pedoman Penanganan Perkara Lingkungan Hidup, ${ }^{21}$ yaitu Notifikasi/somasi wajib diajukan dalam jangka waktu 60 hari kerja

19 Perbedaan pandangan atau penafsiran terkait prosedur notifikasi meliputi jangka waktu pengajuan, pengajuan sebelum atau setelah gugatan, bentuk notifikasi (pemberitahuan tertulis atau somasiterbuka).

20 a). Gugatan citizen lawsuit oleh para penggugat yang mengatasnamakan Masyarakat Pengguna Jalan Tol pada Jalan Tol Lingkar Luar Jakarta (JORR), dalam putusan Nomor 40/Pdt.G/2008/PN.Jkt.Sel tanggal 19 mei 2008 dinyatakan bahwa gugatan para penggugat tidak dapat diterima karena tidak terpenuhinya syarat formil berupa notifikasi

b). Gugatan citizen lawsuit oleh para penggugat yang mengatasnamakan warga Negara pemegang hak untuk memilih dalam Pemilihan Umum (Pemilu) 2009, dalam putusan Nomor 145/Pdt.G/2009/PN. Jkt. Pst tanggal 3 juni 2009, dinyatakan bahwa gugatan para penggugat tidak dapat diterima karena tidak terpenuhinya syarat formil yaitu tidak dapat memenuhi syarat jangka waktu notifikasi.

c). Gugatan citizen lawsuit oleh Tim Advokasi Warga Negara Menggugat (Tawan Gugat) 23 warga negara yang menggugat kemaikan harga Bahan Bakar Minyak Bersubsidi, Majelis Hakim Pengadilan Negeri Jakarta Pusat menyatakan Gugatan Tidak Dapat Diterima karena tidak memenuhi syarat formil berupa Notifikasi.

d). Gugatan citizen lawsuit yang diajukan Masyarakat Sipil untuk Kesejahteraan Rakyat (MSKR) Nusa Tenggara Barat terhadap Newmont Nusa Tenggara, dalam putusan Nomor 241/Pdt.G/2011/PN.Jkt.Pst, dinyatakan bahwa gugatan penggugat tidak dapat diterima karena notifikasi diajukan terlalu singkat dalam waktu 7 hari sehingga tidak memenuhi syarat notifikasi.

21 Keputusan Ketua Mahkamah Agung bukan merupakan peraturan yang berisi ketentuan yang bersifat hukum acara, tetapi merupakan surat keputusan yang dikeluarkan Ketua Mahkamah Agung mengenai suatu hal tertentu, sehingga ketentuan mengenai Notifikasi yang dinyatakan dalam Keputusan Ketua Mahkamah Agung Republik Indonesia Nomor: 36/KMA/SK/II/ 2013 tentang Pemberlakuan Pedoman Penanganan Perkara Lingkungan 
sebelum adanya gugatan dan sifatnya wajib. Apabila tidak ada notifikasi/somasi gugatan wajib dinyatakan tidak dapat diterima; Notifikasi/somasi dari calon penggugat kepada calon tergugat dengan tembusan kepada Ketua Pengadilan Negeri setempat; Jangka waktu 60 hari kerja bertujuan untuk memberikan kesempatan kepada Pemerintah melaksanakan kewajiban hukumnya sebagaimana diminta atau dituntut oleh calon penggugat. ${ }^{22}$

Secara umum pemberitahuan ini bertujuan untuk; a) memberikan dorongan/ insentif bagi pelanggar agar melakukan penataan, b) memberikan kesempatan secara adil kepada tergugat untuk mengajukan bantahan dalam kesempatan paling awal dari proses penanganan perkara, c) kegagalan dalam menyediakan pemberitahuan yang memenuhi syarat dapat dipergunakan sebagai alasan menolak gugatan, d) memberikan pendidikan kepada penggugat untuk menyajikan gugatan dengan dilengkapi bukti dan fakta yang akurat. ${ }^{23}$

Standing penggugat dalam gugatan citizen lawsuit tidak didasarkan atas hubungan kepentingan secara langsung. Gugatan citizen lawsuit dilakukan atas dasar kepentingan umum sedangkan asas utama hukum acara perdata Indonesia adalah asas point d'interet point d'action artinya barang siapa yang mempunyai kepentingan dapat mengajukan tuntutan hak/gugatan ke pengadilan dan asas actori incumbit probation yang artinya barang siapa yang mempunyai sesuatu hak atau mengemukakan suatu peristiwa harus membuktikan adanya hak atau peristiwa itu. ${ }^{24}$ Menurut Elly Kristiani telah terjadi pergeseran asas point d'interset

Hidup tidak mengikat bagi hakim yang memeriksa gugatan citizen lawsuit di luar perkara lingkungan hidup.

22 Catatan Khusus terkait Notifikasi yang dinyatakan dalamKeputusan Ketua Mahkamah Agung Republik Indonesia Nomor: 36/KMA/SK/II/2013 tentang Pemberlakuan Pedoman Penanganan Perkara Lingkungan Hidupadalah Notifikasi/Somasi dalam Citizen Lawsuit (CLS) berbeda dengan notifikasi dalam gugatan Class Action (CA). Dalam gugatan CLS notifikasi/somasi oleh pihak penggugat kepada pemerintah dan ditembuskan ke Pengadilan Negeri setempat dan notifikasi/somasi disampaikan sebelum gugatan diajukan di pengadilan karena isi notifikasi tersebut dipakai sebagai dasar gugatan. Dalam surat gugatan wajib dilampirkan notifikasi/somasi dengan bukti tanda terima pengadilan atau resi surat tercatat, dan notifikasi dalam gugatan CA diajukan atas perintah hakim dengan putusan sela setelah gugatan CA dinyatakan telah memenuhi syarat formalitas untuk sahnya gugatan CA.

23 Abdul Fatah. 2013. Gugatan Warga Negara Sebagai Mekanisme Pemenuhan Hak Asasi Manusia Dan Hak Konstitusional Warga Negara. Jurnal Yuridika Volume 28 No 3, September-Desember. hlm 298.

24 Kekuatan hukum standing penggugat dalam gugatan citizen lawsuit terdapat dua sudut 
point d'action hal ini didasarkan pada hakim memiliki tugas dan fungsi untuk memberikan sisi kemanfaatan dan keadilan hukum bagi pencari keadilan dalam perkara yang diajukan kepadanya, sebagai konsekuensi kewajiban memberikan sisi keadilan, kepastian hukum, dan kemanfataan bagi para pihak hakim dapat menggali hukum yang hidup dalam masyarakat termasuk adopsi dari sistem hukum lain. Sehingga dalam adopsi mekanisme gugatan citizen lawsuit tidak memerlukan asas dasar kepentingan hukum yang cukup bagi penggugat point d'interset point d'action). ${ }^{25}$

Isi petitum yang dapat diajukan dalam gugatan citizen lawsuit mempunyai karakteristik yaitu :26

1. Petitum dalam gugatan tidak boleh meminta adanya ganti rugi materiil, karena warga negara yang menggugat bukan kelompok yang dirugikan secara materiil dan memiliki kesamaan fakta hukum sebagaimana gugatan class action

2. Petitum gugatan citizen lawsuit harus beirisi permohonan agar Negara mengeluarkan suatu kebijakan peraturan umum agar perbuatan melawan hukum berupa kelalaian dalam pemenuhan hak warga Negara tersebut di masa yang akan datang tidak terjadi lagi

3. Petitum citizen lawsuit tidak boleh berupa pembatalan atas Keputusan Penyelenggara Negara (Keputusan Tata Usaha Negara) yang bersifat konkrit dan final karena hal tersebut merupakan kewenangan dari peradilan TUN

4. Petitum citizen lawsuit juga tidak boleh berupa pembatalan atas suatu UndangUndang (UU) karena itu merupakan kewenangan dari Mahkamah Konstitusi (MK). Selain itu, citizen lawsuit juga tidak boleh meminta pembatalan atas

pandang yang berbeda, pertama, dalam sudut pandang citizen lawsuit maka asas point d'interset point d'action dalam hukum acara perdata di Indonesia tidak berlaku, sedangkan pandangan kedua, adalah jika posisi penggugat dilihat dalam sudut hukum acara perdata maka asas point d'interset point d'action mutlak harus dipenuhi karena sifat dari hukum acara perdata adalah bersifat memaksa dan tidak bisa disimpangi.

25 Elly Kristiani Purwendah. Pergeseran Asas point d'interset point d'action Dalam Gugatan Citizen Lawsuit Dan Actio Popularis Sebagai Pemenuhan Asas Manfaat Dalam Peradilan Perdata, Makalah, hlm 10.

26 Mahkamah Agung. 2009. Laporan Penelitian Class Action \& Citizen Lawsuit, Bogor : Badan Penelitian dan Pengembangan dan Pendidikan dan Pelatihan Hukum dan Mahkamah Agung RI. hlm 65. 
peraturan perundang-undangan di bawah undang-undang karena hal tersebut merupakan kewenangan mahkamah Agung (MA) di bawah judicial review.

Karakteristik citizen lawsuit, sebagai berikut; 1) Tergugat dalam citizen lawsuit adalah penyelenggara negara mulai dari presiden dan wakil presiden sebagai pimpinan teratas, menteri dan terus sampai kepada pejabat negara di bidang yang dianggap telah melakukan kelalaian dalam memenuhi hak warga negaranya. 2) Perbuatan melawan hukum yang didalilkan dalam gugatan adalah kelalaian penyelenggara negara dalam pemenuhan hak-hak warga negara, dalam hal ini harus diuraikan bentuk kelalaian apa yang telah dilakukan oleh negara dan hak warga negara apa yang gagal dipenuhi oleh Negara. 3) Penggugat adalah warga Negara, yang bertindak mengatasnamakan warga Negara, penggugat dalam hal ini cukup membuktikan bahwa dirinya adalah Warga Negara Indonesia. 4) Memberikan notifikasi kepada penyelenggara negara. 5) Petitum tidak boleh meminta ganti rugi, petitum citizen lawsuit berupa permohonan agar Negara mengeluarkan suatu kebijakan yang mengatur umum (Regeling) agar perbuatan melawan hukum berupa kelalaian dalam pemenuhan hak warga Negara tersebut di masa yang akan datang tidak terulang kembali. ${ }^{27}$

Unsur-unsur dalam gugatan citizen lawsuit sebagai upaya mengatasi kabut asap untuk mendapatkan lingkungan udara yang baik dan sehat, antara lain :

a. Setiap orang atau setiap warga Negara

Setiap orang pada hakikatnya tidak mendapat halangan untuk dapat mengajukan gugatan citizen lawsuit, karena setiap orang memiliki standing untuk mengajukan gugatan tanpa mensyaratkan adanya kerugian yang bersifat nyata dan langsung pada dirinya, dengan membuktikan bahwa ia adalah Warga Negara Indonesia.

b. Kepentingan Umum

Unsur kepentingan umum merupakan dasar utama dalam gugatan citizen lawsuit. Persoalan kabut asap merupakan pencemaran udara yang telah banyak membawa akibat baik berupa kesehatan bahkan kematian,, ${ }^{28}$ serta

27 Abdul Fatah. Op.Cit. hlm 297.

28 Berdasarkan data yang disampaikan Menteri Sosial Khofifah Indar Parawansa, jumlah ko- 
dampak sosial ekonomi lainnya. Sehingga aspek kepentingan umum terpenuhi.

c. Perbuatan Melawan Hukum

Unsur perbuatan melawan hukum adalah berupa kelalaian penyelenggara negara dalam mengatasi kabut asap, sehingga dampaknya sampai meluas dan terjadi dalam hitungan bulan, sehingga masyarakat tidak mendapatkan udara yang sehat.

d. Petitum

Petitum dalam citizen lawsuit harus berisi tuntutan agar pemerintah mengeluarkan suatu kebijakan peraturan umum untuk mengatasi persoalan kabut asap.

\section{Potensi Mengatasi Kabut Asap Melalui Mekanisme Citizen Lawsuit}

Gugatan citizen lawsuit telah diterima dalam sistem peradilandi Indonesia, meskipun belum diatur secara khusus dalam peraturan. Gugatan citizen lawsuit telah mendorong terbentuknya beberapa peraturan perundang-undangan dan kebijakan yang berkaitan dengan pokok permasalahan dalam gugatan.Contoh pengaruh gugatan citizen lawsuit terhadap lahirnya undang-undang adalah putusan Nomor 28/Pdt.G/2003/PN.JKT.PST mengenai kasus penelataran buruh migran di Nunukan yang diputus tanggal 8 Desember 2003 mendorong terbentuknya Undang-Undang Nomor 39 Tahun 2004 Tentang Penempatan dan Perlindungan Tenaga Kerja Indonesia yang disahkan dan diundangkan pada tanggal 18 Oktober 2004. Undang-undang Penempatan dan Perlindungan Tenaga Kerja Indonesia juga mengamanatkan dibentuknya Badan Nasional Penempatan dan Perlindungan Tenaga Kerja Indonesia (BNP2TKI).

Selanjutnya gugatan citizen lawsuit dalam kasus Ujian Nasional putusan Nomor 2596 K/PDT/2008 jo putusan Nomor 377/PDT/2007/PT.DKI jo putusan Nomor 228/PDT/G/2006 memberikan suatu kabar gembira bagi siswa peserta Ujian Nasional dengan dikeluarkannya kebijakan bahwa penentuan kelulusan

rban meninggal dunia akibat kabut asap tahun 2015 sebanyak 19 orang, 5 orang di Kalimantan Tengah, 5 orang di Sumatera Selatan, 5 orang di Riau, 1 orang di Jambi dan 3 orang di Kalimantan Selatan. Lihat Ini Jumlah Korban Meninggal Korban Kabut Asapversi Mensos, JPNN.com. 28 Oktober 2015, diakses tanggal 24 Maret 2016. 
siswa tidak lagi semata-mata didasarkan pada hasil nilai Ujian Nasional, namun dengan melakukan penggabungan nilai-nilai selama proses belajar mengajar di satuan pendidikan dengan nilai hasil Ujian Nasional.

Citizen lawsuit terkait penyelenggaraan jaminan sosial dengan nomor perkara 278/Pdt.G/2010/PN.Jkt.Pst yang diputus pada tanggal 13 Juli 2011 merupakan salah satu faktor yang melatarbelakangi disusunnya Rancangan Undang-Undang tentang Badan Penyelenggara Jaminan Sosial (RUU tentang BPJS) sebagai usul inisiatif Dewan Perwakilan Rakyat. RUU tentang BPJS selanjutnya disahkan dan diundangkan pada tanggal 25 November 2011.

Perkara perlindungan hukum kepada pekerja rumah tangga yang diajukan oleh Jaringan Nasional Advokasi Pekerja Rumah Tangga (Jala PRT) yang diputus dengan putusan Nomor 146/Pdt.G/2011/PN.Jkt.Pst pada tanggal 7 Pebruari 2012 mendorong DPR untuk segera melakukan pembahasan RUU tentang Perlindungan Pekerja Rumah Tangga. ${ }^{29}$

Khusus berkaitan dengan persoalan mengatasi kabut asap, maka melalui gugatan citizen lawsuit juga mempunyai potensi untuk mendorong terbentuknya peraturan perundang-undangan dan kebijakan. Riau merupakan salah satu wilayah yang paling parah terdampak asap akibat kebakaran hutan dan lahan pada tahun 2015, masyarakat Riau melalui Gerakan Riau Melawan Asap ${ }^{30}$ yang terdiri dari empat organisasi kemasyarakatan di Provinsi Riau (Lembaga Adat Melayu Riau, Wahana Lingkungan Hidup Riau, Rumah Budaya Sikukeluang dan Jaringan Kerja Penyelamat Hutan Riau) telah mengajukan gugatan citizen lawsuitdi Pengadilan Negeri Pekanbaru. Pihak yang digugat adalah Presiden Indonesia, Menteri Lingkungan Hidup dan Kehutanan, Menteri Pertanian, Kepala Badan Pertahanan Nasional dan Gubernur Riau pada Maret 2016. ${ }^{31}$ Sesuai dengan isi ketentuan dalam Keputusan Ketua Mahkamah Agung Republik Indonesia Nomor: 36/KMA/SK/ II/2013 tentang Pemberlakuan Pedoman Penanganan Perkara Lingkungan Hidup

29 Febry Liany. 2014. Peranan Gugatan Warga Negara Dalam Pembentukan Hukum Di Indonesia, Jurnal Prodigy Vol 2 No 2 - Desember. hlm 265.

30 Hal yang sama juga dilakukan oleh Gerakan Anti Asap (GAAs) Kalimantan Tengah yang telah menyampaikan notifikasicitizen lawsuit. Lihat Rakyat Kalteng Resmi Gugat 7 Lembaga Negara, www.menara.com, tanggal 10 Maret 2016. Diakses tanggal 24 Maret 2016.

31 Kebakaran Hutan: Gugat Presiden dan 4 Menteri, 4 Organiasai di Riau Ajukan Citizen Law Suit, bisnis.com. tanggal 10 Maret 2016, diakses tanggal 24 Maret 2016. 
maka gugatan citizen lawsuit ini telah diawali dengan menyampaikan notifikasi kepada calon tergugat. Namun karena setelah 60 hari sejak notifikasi disampaikan pihak tergugat tidak memberikan respon atas notifikasi, maka pihak penggugat menindaklanjuti dengan mengajukan gugatan citizen lawsuit. ${ }^{32}$ Persidangan dilakukan menurut ketentuan hukum acara perdata yang diawali dengan mediasi. Mediasi yang dilakukan berhasil membuat kesepakatan damai antara para pihak. ${ }^{33}$ Konsep perdamaian yang dihasilkan dalam gugatan citizen lawsuit terhadap persoalan kabut asap di Riau menunjukan bahwa mengatasi kabut asap sebagai implikasi dari kebakaran hutan lahan tidak saja menuntut peran pemerintah semata, namun diperlukan juga peran serta masyarakat dalam pencegahan dan penanganan kebakaran hutan dan lahan. Poin yang dapat digaris bawahi dari hasil gugatan citizen lawsuit terkait kabut asap di Riau adalah telah menghasilkan adanya komitmen pihak pemerintah untuk menerbitkan suatu kebijakan yang pro terhadap kepentingan lingkungan untuk menyelesaikan persoalan asap khususnya di Provinsi Riau dan tentunya juga wilayah lain di Indonesia.

Hak atas lingkungan yang baik dan sehat yang telah dijamin oleh konstitusi yang bermakna melakukan perlindungan. Apabila dalam implementasinya terdapat tindakan pembiaran oleh penyelenggara negara yang merugikan warga negara untuk memperoleh udara yang sehat, maka melalui mekanisme gugatan citizen lawsuit terhadap kabut asap dapat menjadi dasar agar pemerintah segera membuat peraturan untuk mengatasi kabut asap yang lebih komprehensif, tidak saja dalam bentuk undang-undang, peraturan pelaksana undang-undang maupun berupa kebijakan.

32 Masyarakat Riau Gugat Negara Terkait Kasus Asap, geotimes.co.id. tanggal 11 Maret 2016, diakses tanggal 24 Maret 2016.

33 Kesepakatan damai yang tertuang dalam Akta Perdamaian yaitu 1). Para tergugat berkomitmen bersama-sama menanggulangi kebakaran hutan dan lahan melalui tindakan-tindakan dan penerbitan kebijakan guna menyelesaikan persoalan asap yang terjadi di Provinsi Riau, 2). Para penggugat berkomitmen untuk berperan serta aktif dalam pencegahan dan penanganan kebakaran hutan dan lahan di Provinsi Riau, 3). Tergugat I dan Tergugat II segera menyelesaikan Peraturan Pelaksana dari Undang-Undang Nomor 32 Tahun 2009 tentang Perlindungan dan Pengelolaan Lingkungan Hidup, 4). Tergugat bersedia untuk mengalokasikan dana penanggulangan bencana dalam APBN dan APBD dengan memperhatikan kemampuan keuangan Negara, dan 5). Tergugat setuju untuk memperkuat fasilitas pelayanan korban kebakaran hutan dan lahan serta mengembangkan sistem informasi kebakaran hutan, lahan dan perkebunan di wilayah Provinsi Riau. Lihat CLS : Gugatan Kabut Asap Di Riau Pengadilan Negeri Pekanbaru,Metropekanbaru.com. tanggal 24 Mei 2016, diakses tanggal 30 Mei 2016. 


\section{Simpulan dan Rekomendasi}

Citizen lawsuit telah diterima sebagai bagian dari penyelesaian persoalan lingkungan khususnya dalam lingkup perdata. Citizen lawsuitmerupakan hak gugat warga negara atas kepentingan umum, sebagai perwujudan akses individual/ orang perorangan warga negara untuk kepentingan keseluruhan warga negara atau kepentingan umum menggugat tanggung jawab penyelenggara negara atas kelalaian dalam memenuhi hak-hak warga negara. Persoalan kabut asap yang mengakibatkan warga negara tidak mendapatkan haknya atas lingkungan udara yang baik dan sehat dapat di jadikan sebagai dasar gugatan citizen lawsuit, apabila unsur-unsur terkait adanya kelalaian penyelenggara negara dan demi kepentingan umum dapat terpenuhi.

Potensi menggunakan mekanisme citizen lawsuit sebagai upaya mengatasi kabut asap, merupakan suatu keniscyaan karena tuntutan yang diminta oleh warga negara dalam gugatannya adalah agar pemerintah mengeluarkan peraturan baik dalam bentuk undang-undang, peraturan pelaksana, atau melakukan tindakantindakan tertentu lainnya merupakan upaya preventif maupun refresif untuk mengatasi persoalan kabut asap agar tidak lagi terulang di masa yang akan datang.

Pemerintah seyogyanya memformulasikan mekanisme citizen lawsuit sebagai hukum formil Indonesia, sehingga dapat digunakan sebagai upaya penegakan hukum yang legimate. Mengingat ketika penyelenggara negara melakukan kelalaian dalam memenuhi hak warga negara, melalui mekanisme citizen lawsuit hak-hak yang terabaikan dapat dipulihkan dan tidak terulang kembali. 


\section{DAFTAR PUSTAKA}

Fakhriah, Efa Laela. 2008.Actio Popularis (Citizen Lawsuit) Dalam Perspektif Hukum Acara Perdata. Makalah.

Fatah, Abdul. 2013.Gugatan Warga Negara Sebagai Mekanisme Pemenuhan Hak Asasi Manusia Dan Hak Konstitusional Warga Negara. Jurnal Yuridika Volume 28 No 3, September-Desember.

Firdaus, Muhammad Syafari (et.all).2007. Pembangunan Berbasis Hak Asasi Manusia: Sebuah Panduan. Jakarta : Komisi Nasional HAM Bekerjasama dengan Australian Government (AusAID).

Gumayra, Dhabi K(Kontributor). 2006. Panduan Bantuan Hukum di Indonesia. Jakarta : Aussaid YLBHI, PSHK dan IALDF.

Hardjasoemantri, Koesnadi. 1983.Hukum Tata Lingkungan. Cetakan ke-1, Yogyakarta : Gadjah Mada University Press.

Huijber, Theo, 2000. Filsafat Hukum Dalam Lintasan Sejarah. Jakarta : UI Press.

Isrok dan Rizki Emil Birham. 2010.Citizen Lawsuit : Penegakan Hukum Alternatif bagi Warga Negara. Malang: UB Press.

Liany, Febry. 2014. Peranan Gugatan Warga Negara Dalam Pembentukan Hukum Di Indonesia. Jurnal Prodigy Vol 2 No 2 - Desember.

Mahkamah Agung. 2009. Laporan Penelitian Class Action E Citizen Lawsuit. Bogor : / Badan Penelitian dan Pengembangan dan Pendidikan dan Pelatihan Hukum dan Mahkamah Agung RI.

Muhjad, Hadin. 2015.Hukum Lingkungan : Sebuah Pengantar Untuk Konteks Indonesia. Yogyakarta : Genta Publishing.

Nugroho, Susanti Adi. 2010. Class Action dan Perbandingannya Dengan Negara Lain. Cetakan 1, Jakarta : Prenadia Media Group.

Purwendah, Elly Kristiani. Pergeseran Asas point d'interset point d'action Dalam Gugatan Citizen Lawsuit Dan Actio Popularis Sebagai Pemenuhan Asas Manfaat Dalam Peradilan Perdata. Makalah. 
Sugiantoro, Indro. 2004. Kasus Nunukan : Hak Gugat Warga Negara (Citizen Lawsuit) Terhadap Negara. Jurnal Kajian Putusan Pengadilan Dictum, Edisi 2.

\section{Artikel Internet :}

Asap Kebakaran Hutan Sampai Jakarta, www.bbc.com>Indonesia>2015. tanggal 24 Oktober 2015. Diakses tanggal 10 Pebruari 2016.

BNPB : Kebakaran Hutan 2015 Seluas 32 Wilayah DKI, CNN Indonesia.com, tanggal 31 Oktober 2015, diakses tanggal 24 Maret 2016.

CLS : Gugatan Kabut Asap Di Riau Pengadilan Negeri Pekanbaru,Metropekanbaru. com. tanggal 24 Mei 2016, diakses tanggal 30 Mei 2016.

Ini Jumlah Korban Meninggal Korban Kabut Asap versi Mensos, JPNN.com. 28 Oktober 2015, diakses tanggal 24 Maret 2016.

Kebakaran Hutan: Gugat Presiden dan 4 Menteri, 4 Organiasai di Riau Ajukan Citizen Law Suit, bisnis.com. tanggal 10 Maret 2016, diakses tanggal 24 Maret 2016.

Masyarakat Riau Gugat Negara Terkait Kasus Asap, geotimes.co.id. tanggal 11 Maret 2016, diakses tanggal 24 Maret 2016

Rakyat Kalteng Resmi Gugat 7 Lembaga Negara, www.menara.com, tanggal 10 Maret 2016. Diakses tanggal 24 Maret 2016.

Tiga Bulan, Hutan dan Lahan Terbakar Setara 4 kali Luas Bali.Mongabay.com Situs Berita Informasi Lingkungan, tanggal 31 Oktober 2015, di akses tanggal 24 Maret 2016.

10 Tewas, 503 Ribu Jiwa ISPA, dan 43 Juta Jiwa Terpapar Asap, BNPB.go.id, tanggal 24 Oktober 2015, diakses tanggal 24 Maret 2016. 